\title{
P301: The blood exposure accidents to hospital regional of Tenkodogo
}

\author{
J Zoungrana ${ }^{1 *}, \mathrm{~A} \mathrm{SO}^{2}$ \\ From 2nd International Conference on Prevention and Infection Control (ICPIC 2013) \\ Geneva, Switzerland. 25-28 June 2013
}

\section{Introduction}

Accidental blood exposure (AES), whether occurring during professional activities or not, is defined by contact with blood or blood-containing liquid at a prick with a needle, a cut with a sharp objects or by contact with blood or contaminated liquid from a wound, non-intact skin or mucous membranes.

To date, very few studies have been conducted in the field of AES in Burkina Faso.

\section{Objectives}

- To study the mechanisms of occurrence of AES at CHR Tenkodogo,

- To identify the main causes of AES,

- To identify occupational groups at risk of AES,

- To evaluate the support provided by the hospital for victims of AES.

\section{Methods}

- 1 week, cross-sectional descriptive study (March to 10 March 2011).

- Data collection performed using a self-administered questionnaire.

\section{Results}

$60 \%$ of patients reported no exposure to blood. In $90.9 \%$ of cases of blood exposure accidents are occurring in health care administration. Needle-stick injury is the most prevalent in a proportion of about $50 \%$. Most needle-stick injuries involved the fingers. In $86.4 \%$ of cases, the contaminating liquid was blood. The general surgery service is by far the one who pays the brunt of exposure to blood in a proportion of $34.7 \%$ (19.6\% in surgery and $15.2 \%$ at PO block) followed générale15 Medicine Department, $22 \%$ of $82.3 \%$ of victims AES. AES did not

${ }^{1}$ RIPAQS, Burkinabe Association for Improving Patient Safety, Burkina Faso Full list of author information is available at the end of the article meet protocol support $18.8 \%$ of those exposed have received ARV treatment $25.6 \%$ of cases of BSE reported $\mathrm{n}$ have received no support.

\section{Conclusion}

It is important for healthcare facilities to implement monitoring of AES to evaluate prevention policies.

\section{Disclosure of interest}

None declared.

\section{Author details}

${ }^{1}$ RIPAQS, Burkinabe Association for Improving Patient Safety, Burkina Faso. ${ }^{2} \mathrm{CHR}$ Tenkodogo Tenkodogo, Ministry of Health, Ouagadougou, Burkina Faso.

Published: 20 June 2013

doi:10.1186/2047-2994-2-S1-P301

Cite this article as: Zoungrana and SO: P301: The blood exposure accidents to hospital regional of Tenkodogo. Antimicrobial Resistance and Infection Control 2013 2(Suppl 1):P301.

Submit your next manuscript to BioMed Central and take full advantage of:

- Convenient online submission

- Thorough peer review

- No space constraints or color figure charges

- Immediate publication on acceptance

- Inclusion in PubMed, CAS, Scopus and Google Scholar

- Research which is freely available for redistribution
C Biomed Central

(c) 2013 Zoungrana and SO; licensee BioMed Central Ltd. This is an Open Access article distributed under the terms of the Creative Commons Attribution License (http://creativecommons.org/licenses/by/2.0), which permits unrestricted use, distribution, and reproduction in any medium, provided the original work is properly cited. 